\title{
Mutational analysis of the tyrosine kinome in serous and clear cell endometrial cancer uncovers rare somatic mutations in TNK2 and DDR1
}

Meghan L Rudd', Hassan Mohamed', Jessica C Price ${ }^{1}$, Andrea J O'Hara ${ }^{1}$, Matthieu Le Gallo', Mary Ellen Urick', NISC Comparative Sequencing Program ${ }^{2}$, Pedro Cruz ${ }^{3}$, Suiyuan Zhang ${ }^{3}$, Nancy F Hansen ${ }^{3}$, Andrew K Godwin ${ }^{4}$, Dennis C Sgroi ${ }^{5}$, Tyra G Wolfsberg ${ }^{3}$, James C Mullikin ${ }^{2,3}$, Maria J Merino ${ }^{6}$ and Daphne W Bell ${ }^{{ }^{*}}$

\begin{abstract}
Background: Endometrial cancer (EC) is the $8^{\text {th }}$ leading cause of cancer death amongst American women. Most ECs are endometrioid, serous, or clear cell carcinomas, or an admixture of histologies. Serous and clear ECs are clinically aggressive tumors for which alternative therapeutic approaches are needed. The purpose of this study was to search for somatic mutations in the tyrosine kinome of serous and clear cell ECs, because mutated kinases can point to potential therapeutic targets.
\end{abstract}

Methods: In a mutation discovery screen, we PCR amplified and Sanger sequenced the exons encoding the catalytic domains of 86 tyrosine kinases from 24 serous, 11 clear cell, and 5 mixed histology ECs. For somatically mutated genes, we next sequenced the remaining coding exons from the 40 discovery screen tumors and sequenced all coding exons from another 72 ECs (10 clear cell, 21 serous, 41 endometrioid). We assessed the copy number of mutated kinases in this cohort of 112 tumors using quantitative real time PCR, and we used immunoblotting to measure expression of these kinases in endometrial cancer cell lines.

Results: Overall, we identified somatic mutations in TNK2 (tyrosine kinase non-receptor, 2) and DDR1 (discoidin domain receptor tyrosine kinase 1) in 5.3\% (6 of 112) and 2.7\% (3 of 112) of ECs. Copy number gains of TNK2 and DDR1 were identified in another $4.5 \%$ and $0.9 \%$ of 112 cases respectively. Immunoblotting confirmed TNK2 and DDR1 expression in endometrial cancer cell lines. Three of five missense mutations in TNK2 and one of two missense mutations in DDR1 are predicted to impact protein function by two or more in silico algorithms. The $\mathrm{TNK}^{\mathrm{P} 761 \mathrm{Rfs}^{*} 72}$ frameshift mutation was recurrent in $\mathrm{EC}$, and the DDR1 ${ }^{\mathrm{R} 70 \mathrm{Q}}$ missense mutation was recurrent across tumor types.

Conclusions: This is the first study to systematically search for mutations in the tyrosine kinome in clear cell endometrial tumors. Our findings indicate that high-frequency somatic mutations in the catalytic domains of the tyrosine kinome are rare in clear cell ECs. We uncovered ten new mutations in TNK2 and DDR1 within serous and endometrioid ECs, thus providing novel insights into the mutation spectrum of each gene in EC.

Keywords: Endometrial, Cancer, Mutation, TNK2, ACK1, DDR1, Copy number, Tyrosine kinase, Tyrosine kinome

\footnotetext{
* Correspondence: belldaph@mail.nih.gov

${ }^{1}$ Cancer Genetics Branch, National Human Genome Research Institute,

National Institutes of Health, Bethesda, MD 20892, USA

Full list of author information is available at the end of the article
} 


\section{Background}

Endometrial carcinomas (ECs) arise from the inner epithelial lining of the uterus and can be classified into a number of discrete histological subtypes (reviewed in [1]). Endometrioid endometrial carcinomas (EECs) represent the vast majority of diagnosed cases [1]. They are generally estrogen-dependent tumors that are associated with a number of well-established epidemiological risk factors that lead to unopposed estrogen exposure including obesity, nulliparity, early age at menarche, and late age at menopause [2]. Most EECs are detected at an early clinical stage when surgery or surgery with adjuvant radiotherapy can often be curative $[3,4]$.

Serous and clear cell ECs are high-grade tumors that are rare at diagnosis but are clinically aggressive and contribute substantially to mortality from endometrial cancer (reviewed in [5]). For example, in a large retrospective study of 5,694 cases of endometrial cancer in the US, serous and clear cell tumors together represented $13 \%$ of diagnoses but accounted for $47 \%$ of deaths [6]. Historically, serous and clear cell ECs are considered to be estrogen-independent tumors with no well-established epidemiological risk factors other than increasing age $[7,8]$. However, a recent large epidemiological study has suggested that increased body mass index may be a risk factor for serous endometrial carcinomas [9]. Current therapeutic approaches to treat patients with serous or clear cell ECs are variable but generally include surgery and adjuvant chemotherapy and/or radiotherapy $[10,11]$.

Alternative therapeutic options are being sought for patients with serous or clear cell EC and for patients with advanced-stage or recurrent endometrioid EC. Rationallydesigned therapeutics targeting tyrosine kinases can be clinically efficacious against tumors that have somatically mutated, amplified, or rearranged the target kinase, and which are dependent on the aberrant kinase-mediated signaling for their survival [12-17]. Recently, the tyrosine kinase gene family has been sequenced in 133 serous ECs, 329 endometrioid ECs, 53 ECs of unspecified histology, and 13 mixed histology ECs either by targeted sequencing of the tyrosine kinome [18], or by comprehensive sequencing of all protein-encoding genes including the tyrosine kinome [19-24]. However, it has been estimated that at least 500 tumors of a given histology need to be sequenced to provide adequate statistical power to reliably detect mutations occurring at a frequency of at least $3 \%$ in a particular histotype [25]. Therefore, sequencing tyrosine kinase genes in additional serous ECs may shed further insights into the frequency and spectrum of mutations in potentially druggable targets in this clinically aggressive subtype. Moreover, the lack of a systematic search for mutations in the tyrosine kinome of clear cell ECs merits such an analysis for this histological subtype.
Here, we performed a mutation discovery screen to determine the incidence of somatic mutations in the catalytic domains of 86 tyrosine kinases in a series of 24 primary serous, 11 clear cell, and 5 mixed (serous-endometrioid) histology ECs. Somatically mutated genes were then resequenced from another $72 \mathrm{ECs}$, and evaluated for copy number alterations in all 112 tumors. We report low-frequency somatic mutations and copy number gains of the TNK2 (tyrosine kinase non-receptor, 2) and DDR1 (discoidin domain receptor tyrosine kinase 1) kinases among the three major histological subtypes of EC.

\section{Methods}

Ethics statement

The NIH Office of Human Subjects Research determined that this research activity was exempt from Institutional Review Board review.

\section{Clinical specimens}

Anonymized, fresh-frozen, primary tumor tissues and matched histologically normal tissues were obtained from the Cooperative Human Tissue Network (100 cases), which is funded by the National Cancer Institute, or from the Biosample Repository at Fox Chase Cancer Center, Philadelphia PA (1 case). DNAs from another 11 cases of fresh-frozen tissue, including all five mixed histology (endometrioid-serous) cases (Additional file 1), were purchased from Oncomatrix. To the best of our knowledge, the mixed-histology tumor tissues were not macrodissected to separate individual histological components prior to DNA extraction by Oncomatrix. The entire cohort of 112 cases consisted of 45 serous, 21 clear cell, 41 endometrioid, and 5 mixed histology ECs. The endometrioid cases consisted of grade $1(n=26)$, grade $2(n=12)$, grade $2 / 3(n=1)$, and grade $3(n=2)$ tumors (Additional file 1). All primary tumor tissues were collected prior to treatment. For tumor tissues $(n=100)$ procured from CHTN, a hematoxylin and eosin (H\&E) stained section was cut from each tumor specimen and reviewed by a pathologist to verify histology and to delineate regions of tissue with a tumor cell content of $\geq 70 \%$.

\section{Nucleic acid isolation}

Genomic DNA was isolated from macrodissected tissue with greater than $70 \%$ tumor cellularity using the Puregene kit (Qiagen).

\section{Identity testing}

Paired tumor-normal DNA samples were genotyped using the Coriell Identity Mapping kit (Coriell). Genotyping fragments were size separated on an ABI-3730xl DNA analyzer (Applied Biosystems). Alleles were scored using GeneMapper software. 


\section{Primer design, PCR amplification, nucleotide sequencing and variant calling}

M13-tailed primer pairs (Additional file 2) were designed to target 577 of 591 exons that encode the catalytic domains of the 86 protein tyrosine kinases (Additional file 3), using previously published methods [26]. Sequence constraints precluded the design of primers for 14 of 591 exons. Primers were also designed to target the exons that encode the exonuclease domain (exons 3 to 13) of POLE (polymerase (DNA directed), epsilon, catalytic subunit) and are available on request. PCR amplification conditions are available upon request. Bidirectional Sanger sequencing of PCR products and subsequent nucleotide variant calling were performed as previously described [27]. Variant positions were cross-referenced to the dbSNP (Build 129) database to annotate and exclude known germline variants. To determine whether novel variants were somatic mutations or germline variants, the appropriate tumor DNA and matched normal DNA were re-amplified in an independent PCR followed by sequence analysis of the variant position. Primers used in the secondary screen of TNK2 and DDR 1 are provided in Additional file 4.

\section{Quantitative real-time PCR}

Predesigned primers targeting TNK2 (VPH103-1002824A), DDR1 (VPH106-0859748A) and B2M (beta-2-microglobulin) (VPH115-0515670A) were purchased from SABiosciences (Qiagen). Reactions were assembled to contain either Taqman control genomic DNA (Applied Biosystems) or $2 \mathrm{ng}$ of tumor genomic DNA, $2 \mu \mathrm{l}$ of primers (diluted 1:4), $3.5 \mu$ SYBR Green Rox qPCR mastermix (Qiagen), to a final $10 \mu \mathrm{l}$ reaction volume. qPCR was preformed on a ABI 7900 HT Fast Real-Time PCR System (Applied Biosystems) with the following cycle conditions: $50^{\circ} \mathrm{C}$ for $2 \mathrm{~min}, 95^{\circ} \mathrm{C}$ for $10 \mathrm{~min}$, and 40 cycles of $95^{\circ} \mathrm{C}$ for $15 \mathrm{sec}$ and $60^{\circ} \mathrm{C}$ for $1 \mathrm{~min}$. A standard curve was generated with Taqman control genomic DNA, to permit a determination of the absolute quantitation using SDS 2.4 software (Applied Biosystems). For each experiment, tumor samples were assayed in triplicate for the target gene and control gene $(B 2 M)$. For each sample, the mean quantity of each target gene was normalized to the mean quantity of $B 2 M$. For tumors displaying copy number gains (defined here as a $\geq 3$-fold increase of the target gene compared to $B 2 M$ ), the matched normal DNAs were analyzed to confirm that the copy number gain was somatic. Three independent experiments were performed for each tumor and normal pair. The fold change in somatic copy number was determined by dividing the normalized mean quantity of the target gene in the tumor sample by the normalized mean quantity of the target gene in the matched normal sample. In addition, a 2-tailed Student $t$-test was used to calculate statistical significance.

\section{Estimation of statistical power of study design}

The estimated power to detect one gene mutation in a set of 40 tumors was calculated as $1-(1-X)^{\wedge} 40$, where $X$ is the actual fraction of tumors with a mutation in that gene (Additional file 5).

\section{Cell lines and immunoblotting}

Serous endometrial cancer cell lines (ARK1 and ARK2) were kindly provided by Dr. Alessandro Santin (Yale School of Medicine). RL-95-2, HEC1A, HEC1B, KLE were obtained from the American Type Culture Collection, or the National Cancer Institute's Developmental Therapeutics Program. RL95-2 was established from a grade 2 moderately differentiated adenosquamous carcinoma of the endometrium [28], KLE was established from a poorly differentiated endometrial carcinoma [29], HEC1A was established from a human moderately differentiated endometrial adenocarcinoma [30,31], and HEC1B is a subline of HEC1A $[31,32]$. Cells were washed in phosphatebuffered saline then lysed with ice-cold RIPA buffer (Thermo Scientific) containing $1 \mathrm{mM} \mathrm{Na-orthovanadate,}$ $10 \mathrm{mM} \mathrm{NaF}$, and 1X protease inhibitor cocktail (Roche). Lysates were centrifuged and proteins were quantitated with the Bio-Rad protein assay (Bio-Rad 500-0006). Equal amounts $(\mu \mathrm{g})$ of the cleared lysate were denatured at $95^{\circ} \mathrm{C}$ in 2X SDS sample buffer (Sigma) prior to SDS-PAGE and transfer to PVDF membranes (Bio-Rad). Primary and HRP-conjugated secondary antibodies were: $\alpha$ DDR1 (Cell Signaling), $\alpha$ TNK2 (Upstate), $\alpha \beta$-Actin (Sigma), goat antimouse HRP (Cell Signaling), and goat anti-rabbit HRP (Cell Signaling). Immunoreactive proteins were visualized with enhanced chemiluminescence (Pierce).

\section{Results}

\section{The TNK2 and DDR1 tyrosine kinases are somatically} mutated in endometrial carcinomas

In a mutation discovery screen, we sequenced 577 exons that encode the catalytic domains of 86 tyrosine kinases (Additional file 3), from 24 serous, 11 clear cell, and 5 mixed (serous/endometrioid) histology endometrial carcinomas. We selectively sequenced the catalytic domain of each kinase because this domain can be preferentially mutated in other cancers $[12,15,33]$. For a gene that has kinase domain mutations at an actual frequency of $10 \%$, we estimate that a discovery screen of 24 serous tumors has $92.0 \%$ statistical power to observe at least one mutation (Additional file 5). For a discovery screen of 11 clear cell tumors and 5 mixed histology tumors the corresponding statistical power is estimated to be $68.6 \%$ and $40.9 \%$ respectively (Additional file 5). Six serous tumors (T27, T33, T45, T56, T65, T75) in our discovery screen were previously subjected to whole exome sequencing [19].

We obtained high quality sequence data for $84 \%$ (11.8 Mb) of targeted bases (14.1 Mb). After excluding 
known germline variants, there were 24 nucleotide variants that represented potential somatic mutations. Sequencing of the matched normal DNA revealed that two of the 24 variants were bona fide nonsynonymous somatic mutations. The somatic mutations occurred in TNK2 (Tyrosine kinase non-receptor protein 2) and $D D R 1$ (Discoidin domain receptor tyrosine kinase 1). We therefore extended our analysis of TNK2 and DDR1 to sequence the remaining coding exons from the $40 \mathrm{tu}$ mors in the discovery screen and to sequence all coding exons of TNK2 and DDR1 from another 72 primary endometrial tumors consisting of 10 clear cell, 21 serous, and 41 endometrioid tumors. The secondary screen revealed nine additional nonsynonymous somatic mutations localizing to the catalytic and non-catalytic domains of the encoded proteins (Figure 1, Additional file 6, Additional file 7).

Overall, among the 112 tumors in this study, TNK2 was somatically mutated in $2.2 \%$ ( 1 of 45 ) of serous, $4.8 \%$ ( 1 of 21 ) of clear cell, 7.3\% (3 of 41 ) of endometrioid, and $20 \%$ ( 1 of 5 ) of mixed histology endometrial tumors. DDR1 was somatically mutated in $4.4 \%$ ( 2 of 45 ) of serous tumors and in 2.4\% ( 1 of 41 ) of endometrioid tumors (Table 1). Of the three endometrioid tumors that harbored somatic DDR1 or TNK2 mutations, two cases (T88 and T117) were grade 1 and one case (T131) was grade 3 . Overall, there was no significant difference in the frequency of TNK2/DDR1 mutations between low/ intermediate-grade and high-grade endometrioid ECs; 2 of 38 (5.3\%) low/intermediate-grade (grade 1 or grade 2)

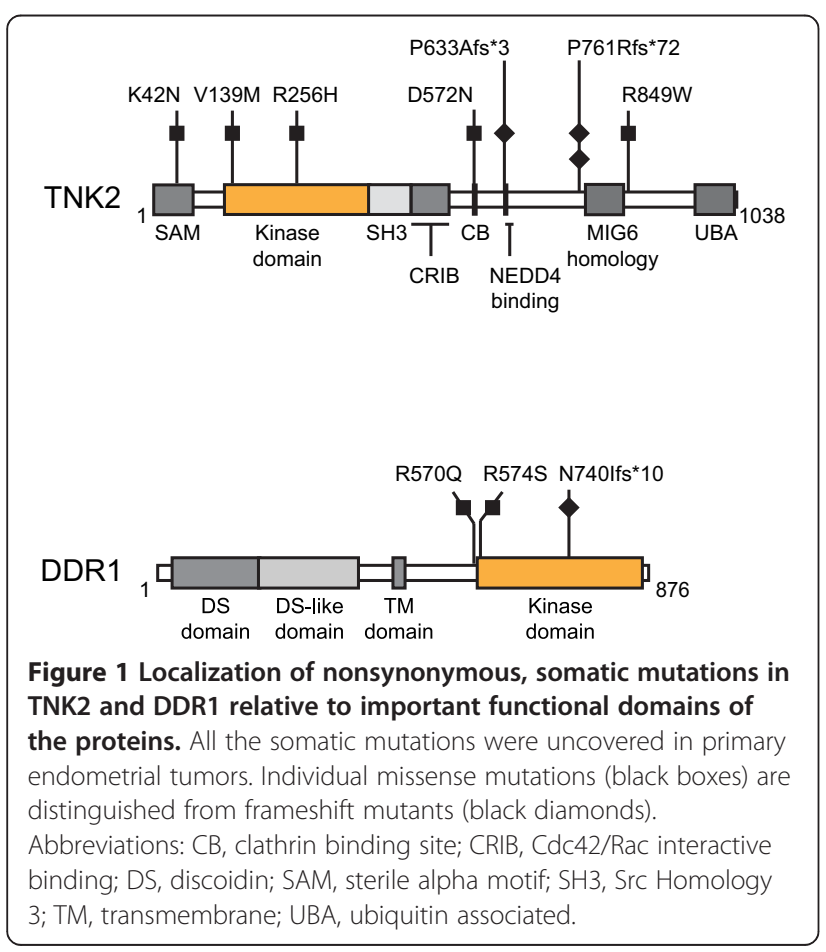

endometrioid ECs had a TNK2 or DDR1 mutation compared with 1 of $3(33.3 \%)$ high-grade (grade $2 / 3$ or 3 ) endometrioid ECs $(P=0.2086)$. The TNK2 ${ }^{\mathrm{D} 572 \mathrm{~N}}$, $\mathrm{TNK} 2^{\mathrm{R} 849 \mathrm{~W}}, \mathrm{TNK} 2^{\mathrm{R} 256 \mathrm{H}}$, and $\mathrm{DDR} 1^{\mathrm{R} 570 \mathrm{Q}}$ missense mutants are predicted, by at least two in silico algorithms, to impact the function of the encoded proteins (Table 1). Immunoblotting confirmed that TNK2 and DDR1 are endogenously expressed in endometrial cancer cells (Figure 2).

\section{Increased copy number of TNK2 and DDR1 in endometrial carcinoma}

We next used quantitative real-time PCR to determine whether TNK2 or DDR1 were affected by copy number alterations among the 112 endometrial tumors in this study. Somatic copy number increases of TNK2 were detected in $8.9 \%$ ( 4 of 45 ) of serous tumors and in $2.4 \%$ (1 of 41) of endometrioid tumors, but in none of the clear cell tumors (Table 2). The single endometrioid tumor displaying a copy number gain of TNK2 was a grade 2 tumor. Somatic copy number increases involving DDR1 were detected in $2.2 \%$ ( 1 of 45 ) of serous tumors (Table 2). For each gene, tumors that displayed copy number alterations were distinct from tumors that had somatic mutations (Additional file 8). Considering mutations and copy number alterations together, TNK2 was somatically altered in $11.1 \%$ ( 5 of 45 ) of serous, $4.8 \%$ ( 1 of 21 ) of clear cell, $9.8 \%$ (4 of 41 ) of endometrioid, and $20 \%$ (1 of 5) of mixed histology tumors and DDR1 was somatically altered in $6.7 \%$ ( 3 of 45 ) of serous and $2.4 \%$ ( 1 of 41 ) of endometrioid tumors but not in clear cell or mixed histology tumors (Additional file 8).

Copy number gains of TNK2 and DDR1 could reflect either targeted gene amplification of these kinases or gain of a multigenic genomic region encompassing these genes. To discriminate between these two possibilities, we interrogated the copy number status of TNK2, DDR1, and their flanking genes within The Cancer Genome Atlas (TCGA) catalogue of somatic alterations in serous and endometrioid ECs [21], via the cBIO Cancer Genomics Portal [34]. In the serous and endometrioid ECs within the TCGA cohort, copy number gains involving TNK2 and $D D R 1$ were not focal but extended to flanking genes.

\section{A subset of TNK2 and DDR1 mutated tumors are POLE-mutant or microsatellite unstable}

Somatic mutations in the exonuclease domain of POLE and/or microsatellite instability (MSI) occur in a subset of ECs and are associated with elevated mutation rates [21]. We therefore sought to determine whether any of the TNK2- or DDR1-mutated cases were coincident with POLE mutations or MSI-positivity. We sequenced exons 3-13 of POLE, which encode the exonuclease domain, from all 112 tumors in our study; the MSI status of 
Table 1 Somatic mutations of TNK2, and DDR1 identified among 112 primary ECs

\begin{tabular}{|c|c|c|c|c|c|c|c|}
\hline \multirow[t]{2}{*}{ Gene } & \multirow[t]{2}{*}{ Tumor ID } & \multirow{2}{*}{$\begin{array}{l}\text { Histology and } \\
\text { grade (G) }\end{array}$} & \multirow{2}{*}{$\begin{array}{l}\text { Nucleotide } \\
\text { change }\end{array}$} & \multirow{2}{*}{$\begin{array}{l}\text { Amino acid } \\
\text { change }\end{array}$} & \multicolumn{3}{|c|}{ In silico functional predictions } \\
\hline & & & & & Mutation assessor & SIFT & Polyphen v2 \\
\hline \multirow[t]{8}{*}{ TNK2 } & $T 3^{a, b}$ & Serous & c.C1887_1888ins C & p.P633Afs*3 & - & - & - \\
\hline & $T 3^{a, b}$ & Serous & C.G1714A & p.D572N & Low & Affects function & Probably damaging \\
\hline & $\mathrm{T} 15^{\mathrm{a}}$ & Mixed & c.G415A & p.V139M & Low & Affects function & Possibly damaging \\
\hline & $\mathrm{T} 77^{\mathrm{C}}$ & Clear cell & c.C2545T & p.R849W & Low & Affects function & Probably damaging \\
\hline & $\mathrm{T} 88^{\mathrm{c}}$ & Endometrioid (G1) & c.G767A & p.R256H & High & Affects function & Probably damaging \\
\hline & $\mathrm{T} 88^{\mathrm{C}}$ & Endometrioid (G1) & c.G126T & p.K42N & Medium & Tolerated & Probably damaging \\
\hline & $\mathrm{T} 117^{\mathrm{C}}$ & Endometrioid (G1) & c.2276 del C & p.P761Rfs*72 & - & - & - \\
\hline & $\mathrm{T} 131$ & Endometrioid (G3) & c.2276 del C & p.P761Rfs*72 & - & - & - \\
\hline \multirow[t]{3}{*}{ DDR1 } & $T 3^{a, b}$ & Serous & C.C1720A & p.R574S & Low & Tolerated & Benign \\
\hline & $\mathrm{T} 79$ & Serous & c.G1709A & p.R570Q & Low & Affects function & Probably damaging \\
\hline & $\mathrm{T} 117^{\mathrm{C}}$ & Endometrioid (G1) & c.2216delA & p.N740lfs*10 & - & - & - \\
\hline
\end{tabular}

Transcript accession numbers: TNK2 (Ensembl ID ENST00000392400), DDR1 (Ensembl ID ENST00000454612). Protein accession numbers: TNK2 (CCDS33928), DDR1 (CCDS4690). G: Grade.

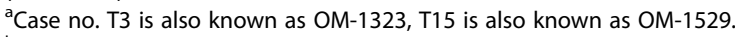

${ }^{\mathrm{b}} \mathrm{POLE}$-mutated.

${ }^{c}$ MSI-positive tumors, as reported previously [19].

*Denotes the position of a new stop codon introduced by the corresponding frameshift ( $\mathrm{fs}$ ) mutation.

tumors in this study has previously been reported [19]. Three tumors had somatically mutated POLE (T3 (c.C890T;p.S297F), T24 (c.1096delT; p.F367Lfs*15), and T97 (c.C857G; p.P286R), Additional file 9). Overall, somatic mutations within the exonuclease domain of POLE were detected in $2.2 \%$ ( 1 of 45 ) of serous, $4.8 \%$ ( 1 of 21 ) of

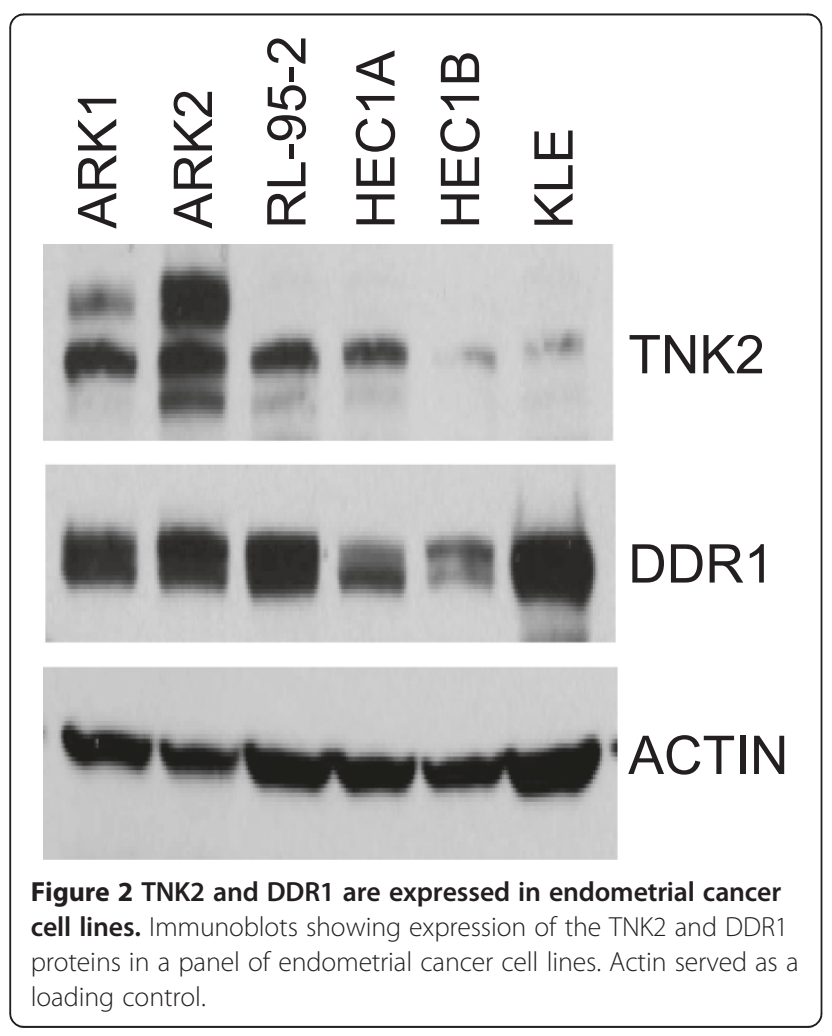

clear cell, and 2.4\% (1 of 41) of endometrioid tumors in our cohort. The frequency of POLE mutations in TNK2-DDR1 mutated cases (1 of 7; 14\%) compared with TNK2-DDR1 non-mutated cases (2 of 105; 2\%) was not statistically significantly different $(P=0.1775)$. Of the seven tumors with TNK2 or DDR1 mutations, one case (T3) had a somatic mutation within POLE $\left(\mathrm{POLE}^{\mathrm{S} 297 \mathrm{~F}}\right)$ and another three cases (T77, T88, and T117) were MSI-positive (Table 1). One of the two frameshift mutations in T117, an MSI-positive tumor, occurred at a polynucleotide $\left(C_{n}\right)$ tract (Additional file 6), suggesting that this mutation (TNK2 $\left.{ }^{\mathrm{P} 761 \mathrm{Rfs}^{*} 72}\right)$ may have arisen as a consequence of defective mismatch repair.

\section{Discussion}

Herein we report the occurrence of low-frequency somatic mutations in the TNK2 and DDR1 kinases among serous, clear cell, and endometrioid ECs. The TNK2 non-receptor tyrosine kinase is activated in response to a variety of stimuli including ligand-dependent stimulation of receptor tyrosine kinases [35], Cdc42 [36], and integrinmediated cell adhesion [37]. TNK2 activation has been implicated in the regulation of cell growth, survival, and integrin-mediated cell adhesion and migration [37-41], and overexpression of TNK2 in cultured cells promotes a metastatic phenotype [37]. The DDR1 receptor tyrosine kinase is activated by triple-helical collagens [42] and has been implicated in the regulation of cell adhesion, survival, proliferation, differentiation, migration, invasion, morphogenesis and development [43-53].

Of the seven endometrial tumors that had somatic mutations in TNK2 and/or DDR1 in our study, one tumor 
Table 2 Copy number gains of TNK2 and DDR1 among 112 primary ECs

\begin{tabular}{lcccc}
\hline Gene & Tumor ID & Histology & Fold Increase in somatic copy number & p-value \\
\hline TNK2 & T25 & Serous & 3.911 & 0.0000426 \\
& T50 & Serous & 3.416 & 0.0018339 \\
& T66 & Serous & 5.065 & 0.0185581 \\
& T83 & Serous & 5.968 & 0.0171938 \\
& T105 & Endometrioid (G2) & 3.374 & 0.0006604 \\
DDR1 & T23 & Serous & 3.019 & 0.0005727 \\
\hline
\end{tabular}

${ }^{5}$ 2-tailed Student $t$-test.

G: Grade.

(T3) was POLE-mutant and three tumors (T77, T88, and T117) were microsatellite-unstable, raising the possibility that the TNK2 and DDR1 mutations in these cases may have arisen as a consequence of replicative and mismatch repair defects respectively. A determination of whether the TNK2 and DDR1 mutations uncovered in this study are pathogenic driver mutations or incidental passenger mutations will ultimately rely on functional studies. In the interim, the potential effects of the TNK2 and DDR1 mutations on protein function can be postulated based on their positions relative to known functional domains of the encoded proteins and on in silico predictions. In this regard, the $\mathrm{TNK} 2^{\mathrm{R} 256 \mathrm{H}}$ mutant occurs within the catalytic loop of TNK2, at a conserved residue that forms a hydrogen bond with an ATP analog [54], and is predicted, in silico, to impact protein function. The TNK2 ${ }^{\mathrm{D} 572 \mathrm{~N}}$ mutant occurs within a motif (LIDF) that is essential for binding to the clathrin heavy chain [55], and is predicted to be deleterious. Because a synthetic mutation $\left(\mathrm{TNK} 2^{\mathrm{D} 572 \mathrm{~A}}\right.$ ) at this precise residue results in loss of clathrin binding [55], we speculate that the somatic TNK2 ${ }^{\mathrm{D} 572 \mathrm{~N}}$ mutant might likewise alter the TNK2-clathrin interaction. The TNK2 ${ }^{\mathrm{P} 761 \mathrm{Rfs}^{*} 72}$ mutant was recurrent in our study occurring in two endometrioid ECs one of which was MSI-positive. The TNK2 ${ }^{\mathrm{P}^{\mathrm{P}} 3 \mathrm{Afs}^{*} 3}$ frameshift mutation may also be recurrent: we observed TNK2 $2^{\text {P633Afs*3 }}$ (chr3:195,595,228-195,595,229 insC; Hg19) in a POLEmutant serous EC and this variant has been catalogued by others in cancer cell lines and tumors although in those instances it has not been subjected to technical validation (URL: http://www.cbioportal.org/public-portal/). Both TNK2 ${ }^{\text {P633Afs"3 }^{* 3}}$ and TNK2 ${ }^{\text {P761Rfs"72 }}$ are predicted to encode truncated forms of TNK2 that lack the UBA (ubiquitin associated) domain, which has been implicated in ligand-dependent proteasomal degradation of TNK2 $[38,56]$. An earlier observation that deletion of the UBA domain of TNK2 results in elevated protein levels [56], together with a report that synthetic C-terminal deletion mutants of TNK2 retain catalytic activity $[57,58]$, raises the possibility that the naturally occurring TNK2 $2^{\mathrm{P}^{2} 33 \mathrm{Afs}^{\mathrm{N}} 3}$ and TNK2 ${ }^{\text {P761Rfs"72 }}$ mutants found in this study might encode elevated levels of truncated but catalytically active proteins.
The three DDR1 mutations we identified in EC consisted of two missense mutations (DDR1 $1^{\mathrm{R} 570 \mathrm{Q}}$ and $\mathrm{DDR} 1^{\mathrm{R} 574 \mathrm{~S}}$ ), and a frameshift mutation (DDR1 ${ }^{\mathrm{N} 740 \mathrm{Ifs} \mathrm{s}^{* 10}}$ ) that occurred in an MSI-positive tumor. The DDR1 $1^{\mathrm{R} 570 \mathrm{Q}}$ missense mutation, which we identified in a case of serous EC that was microsatellite-stable and POLEwildtype, has been identified by others in an endometrioid EC [21], and in a case of metastatic melanoma [59]. Thus, the recurrent nature of the DDR1 $1^{\mathrm{R} 570 \mathrm{Q}}$ mutation across studies suggests it may be a pathogenic event that provides a selective advantage in tumorigenesis, including endometrial tumorigenesis.

In the recent catalogue of genomic alterations reported by TCGA for endometrioid and serous ECs, somatic mutations of TNK2 were documented in $2 \%$ of serous ECs and in $1 \%$ of endometrioid ECs, and somatic mutations of DDR1 were noted in $4 \%$ of serous ECs and $2 \%$ of endometrioid ECs $[21,34,60]$. The eight mutations we uncovered in TNK2 are different to the three TNK2 mutations previously described in EC by TCGA. Similarly, two of the three mutations we describe in $D D R 1$ are unique to this study whereas, as discussed earlier, the third mutation (DDR $1^{\mathrm{R} 570 \mathrm{Q}}, \mathrm{CCDS4690}$; alternatively annotated as DDR1 $1^{\mathrm{R} 607 \mathrm{Q}}, \mathrm{CCDS} 34385$ ) was present in a case of serous EC in this study and in a case of endometrioid EC by TCGA. Therefore, our observations not only validate the recent findings of low frequency somatic mutations in TNK2 and DDR1 in serous and endometrioid ECs by TCGA [21], but extend upon those findings by refining knowledge of the mutation spectrum of TNK2 and DDR1 in EC. Moreover, to our knowledge this is the first systematic search for somatic mutations in the tyrosine kinome of clear cell ECs.

In addition to somatic mutations, we also uncovered copy number gains involving TNK2 at an appreciable frequency in serous and endometrioid ECs $(8.9 \%$ and $2.4 \%$ respectively), and copy number gains involving DDR1 at low frequency (2.2\%) in serous ECs in our study. However, from an analysis of the TCGA endometrial cancer data, increased TNK2 and DDR1 copy number appears to reflect regional gains rather than focal amplification, 
thus making their potential biological relevance in endometrial cancer difficult to predict.

It is worth noting that our study has several limitations. First, our mutation discovery screen was restricted to the exons encoding the catalytic domains of tyrosine kinases and would not have detected mutations present in other exons. Second, our discovery screen did not have high statistical power to detect moderately to infrequently mutated genes (Additional file 5). Third, the use of Sanger sequencing for mutational analysis, in both the discovery screen and subsequent secondary screens of TNK2 and $D D R 1$, may have precluded the identification of subclonal variants that are below the sensitivity of detection by this methodology.

\section{Conclusions}

In conclusion, we have identified rare somatic mutations and copy number alterations involving the TNK2 and DDR1 kinases amongst serous, clear cell, and endometrioid ECs. Our findings validate and extend the observation of TNK2 and DDR1 mutations in serous and endometrioid ECs catalogued by TCGA. To our knowledge, this is the first systematic search for somatic mutations in the tyrosine kinome of clear cell ECs. The recurrent nature of the TNK2 ${ }^{\mathrm{P} 761 \mathrm{Rfs}^{*} 72}$ and DDR1 ${ }^{\mathrm{R} 570 \mathrm{Q}}$ mutants raises the possibility that these may be pathogenic events that bestow a selective advantage in endometrial tumorigenesis. Future mechanistic studies of the somatic mutations reported herein are warranted.

\section{Availability of supporting data}

All data supporting the somatic mutations reported in the manuscript are provided in Additional files 6, 7 and 9. Sanger sequencing files for the entire study will be made available through dbGAP with controlled access.

\section{Additional files}

Additional file 1: Clinicopathological information for the mixed histology and endometrioid ECs in the study cohort.

Additional file 2: PCR primers used in the discovery screen.

Additional file 3: Tyrosine kinase genes analyzed in the mutation discovery screen.

Additional file 4: PCR primers used in the secondary screens of TNK2 and DDR1.

Additional file 5: Estimated statistical power to detect mutations in the discovery screen.

Additional file 6: Sequence traces showing somatic mutations identified in TNK2. Traces encompassing the mutated nucleotide (arrow) in tumor (T) DNA, and corresponding traces from matched normal (N) DNA are displayed.

Additional file 7: Sequence traces showing somatic mutations identified in DDR1. Traces encompassing the mutated nucleotide (arrow) in tumor (T) DNA, and corresponding traces from matched normal (N) DNA are displayed.
Additional file 8: Oncoprints showing the distribution of somatic mutations and copy number alterations of TNK2 and DDR1 among 112 primary endometrial carcinomas in the discovery screen. Individual tumors are displayed as gray bars; somatic mutations are indicated by dark blue bars; somatic copy number gains are indicated by green bars. The overall frequency (\%) of somatic alterations for each histological subtype of endometrial cancer is shown on the right.

Additional file 9: Sequence traces showing somatic mutations identified in exons 3-13 of POLE, which encode the exonuclease domain of POLE. Traces encompassing the mutated nucleotide (arrow) in tumor (T) DNA, and corresponding traces from matched normal (N) DNA are displayed.

\section{Abbreviations}

B2M: Beta-2-microglobulin; DDR1: Discoidin domain receptor tyrosine kinase 1; EC: Endometrial carcinoma; EECs: Endometrioid endometrial carcinomas; H\&E: Hematoxylin and eosin; MSI: Microsatellite instability; POLE: Polymerase (DNA directed) epsilon catalytic subunit; TCGA: The cancer genome atlas; TNK2: Tyrosine kinase non-receptor 2; UBA: Ubiquitin associated.

\section{Competing interests}

DWB is a co-inventor on a patent describing EGFR (Epidermal Growth Factor Receptor) mutations, which is licensed to Genzyme.

\section{Authors' contributions}

DWB designed the study. DWB, MLR, and MEU wrote and edited the manuscript. MJM and DCS reviewed specimen histology. MLR isolated and purified DNA from clinical specimens. MLR and JP performed and analyzed identity tests. MLR, NISC, HM, JP, AJO, MLG performed mutational analyses. SZ, PC, TGW, MLR, HM, JP, AJO, and MLG analyzed mutational data. MLR performed and analyzed the GPCR. MEU performed Western blots. PC, MLR, and JCP designed primers. AKG contributed clinical specimens. NFH performed the power calculation. JCM directed sequencing at NISC. All authors read and approved the final manuscript.

\section{Acknowledgements}

We thank Niraj Travedi for advice on statistical analyses. Funded in part by the Intramural Program of the National Human Genome Research Institute, National Institutes of Health (DWB, TGW, and JCM), by NIH R01CA140323 and the Ovarian Cancer Research Fund (AKG), The Avon Foundation (DCS), National Institute of Health (R01CA112021, DCS), The Department of Defense Breast Cancer Research Program (W81XWH-04-1-0606, DCS), and the NCI SPORE in breast cancer at Massachusetts General Hospital (DCS).

\section{Author details}

${ }^{1}$ Cancer Genetics Branch, National Human Genome Research Institute, National Institutes of Health, Bethesda, MD 20892, USA. ${ }^{2} \mathrm{NIH}$ Intramural Sequencing Center, National Institutes of Health, Bethesda, MD 20892, USA. ${ }^{3}$ Genome Technology Branch, National Human Genome Research Institute, National Institutes of Health, Bethesda, MD 20892, USA. ${ }^{4}$ Department of Pathology and Laboratory Medicine, University of Kansas Medical Center, Kansas, KS 66160, USA. ${ }^{5}$ Molecular Pathology Unit and Center for Cancer Research, Massachusetts General Hospital, 149 13th Street, Charlestown, MA 02129, USA. ${ }^{6}$ Center for Cancer Research, National Cancer Institute, National Institutes of Health, Bethesda, MD 20892, USA.

Received: 29 January 2014 Accepted: 13 November 2014 Published: 26 November 2014

\section{References}

1. Dedes KJ, Wetterskog D, Ashworth A, Kaye SB, Reis-Filho JS: Emerging therapeutic targets in endometrial cancer. Nat Rev Clin Oncol 2011, 8:261-271.

2. Mahboubi E, Eyler N, Wynder EL: Epidemiology of cancer of the endometrium. Clin Obstet Gynecol 1982, 25:5-17.

3. Dinkelspiel HE, Wright JD, Lewin SN, Herzog TJ: Contemporary clinical management of endometrial cancer. Obstet Gynecol Int 2013, 2013:583891.

4. Zighelboim I, Powell MA: Adjuvant treatment for early-stage endometrial cancer. Clin Obstet Gynecol 2011, 54:245-255. 
5. Trope C, Kristensen GB, Abeler VM: Clear-cell and papillary serous cancer: treatment options. Best Pract Res Clin Obstet Gynaecol 2001, 15:433-446.

6. Hamilton CA, Cheung MK, Osann K, Chen L, Teng NN, Longacre TA, Powell MA, Hendrickson MR, Kapp DS, Chan JK: Uterine papillary serous and clear cell carcinomas predict for poorer survival compared to grade 3 endometrioid corpus cancers. Brit J Cancer 2006, 94:642-646.

7. Sherman ME: Theories of endometrial carcinogenesis: a multidisciplinary approach. Mod Pathol 2000, 13:295-308.

8. Webb GA, Lagios MD: Clear cell carcinoma of the endometrium. Am J Obstet Gynecol 1987, 156:1486-1491.

9. Setiawan W, Yang HP, Pike MC, McCann SE, Yu H, Xiang YB, Wolk A, Wentzensen N, Weiss NS, Webb PM, van den Brandt PA, van de Vijver K, Thompson PJ, Strom BL, Spurdle AB, Soslow RA, Shu XO, Schairer C, Sacerdote C, Rohan TE, Robien K, Risch HA, Ricceri F, Rebbeck TR, Rastogi R, Prescott J, Polidoro S, Park Y, Olson SH, Moysich KB, et al: Type I and II endometrial cancers: have they different risk factors? J Clin Oncol 2013, $31: 2607-2618$

10. del Carmen MG, Birrer M, Schorge JO: Uterine papillary serous cancer: a review of the literature. Gynecol Oncol 2012, 127:651-661.

11. Gadducci A, Cosio S, Spirito N, Cionini L: Clear cell carcinoma of the endometrium: a biological and clinical enigma. Anticancer Res 2010, 30:1327-1334.

12. Lynch TJ, Bell DW, Sordella R, Gurubhagavatula S, Okimoto RA, Brannigan BW, Harris PL, Haserlat SM, Supko JG, Haluska FG, Louis DN, Christiani DC, Settleman J, Haber DA: Activating mutations in the epidermal growth factor receptor underlying responsiveness of non-small-cell lung cancer to gefitinib. N Engl J Med 2004, 350:2129-2139.

13. Druker BJ, Sawyers CL, Kantarjian H, Resta DJ, Reese SF, Ford JM, Capdeville $R$, Talpaz M: Activity of a specific inhibitor of the BCR-ABL tyrosine kinase in the blast crisis of chronic myeloid leukemia and acute lymphoblastic leukemia with the Philadelphia chromosome. N Engl J Med 2001, 344:1038-1042.

14. Druker BJ, Talpaz M, Resta DJ, Peng B, Buchdunger E, Ford JM, Lydon NB, Kantarjian H, Capdeville R, Ohno-Jones S, Sawyers CL: Efficacy and safety of a specific inhibitor of the BCR-ABL tyrosine kinase in chronic myeloid leukemia. N Engl J Med 2001, 344:1031-1037.

15. Paez JG, Janne PA, Lee JC, Tracy S, Greulich H, Gabriel S, Herman P, Kaye FJ, Lindeman N, Boggon TJ, Naoki K, Sasaki H, Fujii Y, Eck MJ, Sellers WR, Johnson BE, Meyerson M: EGFR mutations in lung cancer: correlation with clinical response to gefitinib therapy. Science 2004, 304:1497-1500.

16. Kwak EL, Bang YJ, Camidge DR, Shaw AT, Solomon B, Maki RG, Ou SH, Dezube BJ, Janne PA, Costa DB, Varella-Garcia M, Kim WH, Lynch TJ, Fidias P, Stubbs H, Engelman JA, Sequist LV, Tan W, Gandhi L, Mino-Kenudson M, Wei GC, Shreeve SM, Ratain MJ, Settleman J, Christensen JG, Haber DA, Wilner K, Salgia R, Shapiro Gl, Clark JW, et al: Anaplastic lymphoma kinase inhibition in non-small-cell lung cancer. N Engl J Med 2010, 363:1693-1703.

17. Weinstein IB: Cancer. Addiction to oncogenes-the Achilles heal of cancer. Science 2002, 297:63-64.

18. Dutt A, Salvesen HB, Chen TH, Ramos AH, Onofrio RC, Hatton C, Nicoletti R, Winckler W, Grewal R, Hanna M, Wyhs N, Ziaugra L, Richter DJ, Trovik J, Engelsen IB, Stefansson IM, Fennell T, Cibulskis K, Zody MC, Akslen LA, Gabriel S, Wong KK, Sellers WR, Meyerson M, Greulich H: Drug-sensitive FGFR2 mutations in endometrial carcinoma. Proc Natl Acad Sci U S A 2008, 105:8713-8717.

19. Le Gallo M, O'Hara AJ, Rudd ML, Urick ME, Hansen NF, O'Neil NJ, Price JC, Zhang S, England BM, Godwin AK, Sgroi DC, Hieter P, Mullikin JC, Merin MJ, Bell DW: Exome sequencing of serous endometrial tumors identifies recurrent somatic mutations in chromatin-remodeling and ubiquitin ligase complex genes. Nat Genet 2012, 44:1310-1315.

20. Liang H, Cheung LW, Li J, Ju Z, Yu S, Stemke-Hale K, Dogruluk T, Lu Y, Liu X, Gu C, Guo W, Scherer SE, Carter H, Westin SN, Dyer MD, Verhaak RG, Zhang F, Karchin R, Liu CG, Lu KH, Broaddus RR, Scott KL, Hennessy BT, Mills GB: Whole-exome sequencing combined with functional genomics reveals novel candidate driver cancer genes in endometrial cancer. Genome Res 2012, 22:2120-2129

21. The Cancer Genome Atlas Research Network, Kandoth C, Schultz N, Cherniack AD, Akbani R, Liu Y, Shen H, Robertson AG, Pashtan I, Shen R, Benz CC, Yau C, Laird PW, Ding L, Zhang W, Mills GB, Kucherlapati R, Mardis $E R$, Levine DA: Integrated genomic characterization of endometrial carcinoma. Nature 2013, 497:67-73.
22. Kinde I, Bettegowda C, Wang Y, Wu J, Agrawal N, Shih le M, Kurman R, Dao F, Levine DA, Giuntoli R, Roden R, Eshleman JR, Carvalho JP, Marie SK, Papadopoulos N, Kinzler KW, Vogelstein B, Diaz LA Jr: Evaluation of DNA from the Papanicolaou test to detect ovarian and endometrial cancers. Sci Transl Med 2013, 5:167ra164.

23. Kuhn E, Wu RC, Guan B, Wu G, Zhang J, Wang Y, Song L, Yuan X, Wei L, Roden RB, Kuo KT, Nakayama K, Clarke B, Shaw P, Olvera N, Kurman RJ, Levine DA, Wang TL, Shih le M: Identification of molecular pathway aberrations in uterine serous carcinoma by genome-wide analyses. $J$ Nat/ Cancer Inst 2012, 104:1503-1513.

24. Zhao S, Choi M, Overton JD, Bellone S, Roque DM, Cocco E, Guzzo F, English DP, Varughese J, Gasparrini S, Bortolomai I, Buza N, Hui P. Abu-Khalaf M, Ravaggi A, Bignotti E, Bandiera E, Romani C, Todeschini P, Tassi R, Zanotti L, Carrara L, Pecorelli S, Silasi DA, Ratner E, Azodi M, Schwartz PE, Rutherford TJ, Stiegler AL, Mane S, et al: Landscape of somatic single-nucleotide and copy-number mutations in uterine serous carcinoma. Proc Natl Acad Sci U S A 2013, 110:2916-2912.

25. Hudson TJ, Anderson W, Artez A, Barker AD, Bell C, Bernabe RR, Bhan MK, Calvo F, Eerola I, Gerhard DS, Guttmacher A, Guyer M, Hemsley FM, Jennings JL, Kerr D, Klatt P, Kolar P, Kusada J, Lane DP, Laplace F, Youyong L, Nettekoven G, Ozenberger B, Peterson J, Rao TS, Remacle J, Schafer AJ, Shibata T, Stratton MR, Vockley JG, et al: International network of cancer genome projects. Nature 2010, 464:993-998.

26. Chines P, Swift A, Bonnycastle LL, Erdos MR, Mullikin J, NISC, Collins FS: PrimerTile: designing overlapping PCR primers for resequencing. Am J Hum Genet 2005, 77:1257.

27. Rice JC, Pollock LM, Rudd ML, Fogoros SK, Mohamed H, Hanigan CL, Le Gallo M, Program NI, Zhang S, Cruz P, Cherukuri PF, Hansen NF, McManus KJ, Godwin AK, Sgroi DC, Mullikin JC, Merino MJ, Hieter P, Bell DW: Sequencing of candidate chromosome instability genes in endometrial cancers reveals somatic mutations in ESCO1, CHTF18, and MRE11A. PLOS One 2013, 8:e63313.

28. Way DL, Grosso DS, Davis JR, Surwit EA, Christian CD: Characterization of a new human endometrial carcinoma (RL95-2) established in tissue culture. In vitro 1983, 19:147-158.

29. Richardson GS, Dickersin GR, Atkins L, MacLaughlin DT, Raam S, Merk LP, Bradley FM: KLE: a cell line with defective estrogen receptor derived from undifferentiated endometrial cancer. Gynecol Oncol 1984, 17:213-230.

30. Kurarmoto H, Hamano M, Imai M: HEC-1 cells. Hum Cell 2002, 15:81-95.

31. Satyaswaroop PG, Fleming H, Bressler RS, Gurpide E: Human endometrial cancer cell cultures for hormonal studies. Cancer Res 1978, 38:4367-4375.

32. Kuramoto $\mathrm{H}$ : Studies of the growth and cytogenetic properties of human endometrial adenocarcinoma in culture and its development into an established line. Acta Obstet Gynaecol Jpn 1972, 19:47-58.

33. Davies H, Bignell GR, Cox C, Stephens P, Edkins S, Clegg S, Teague J, Woffendin H, Garnett MJ, Bottomley W, Davis N, Dicks E, Ewing R, Floyd Y, Gray K, Hall S, Hawes R, Hughes J, Kosmidou V, Menzies A, Mould C, Parker A, Stevens C, Watt S, Hooper S, Wilson R, Jayatilake H, Gusterson BA, Cooper C, Shipley J, et al: Mutations of the BRAF gene in human cancer. Nature 2002, 417:949-954.

34. Cerami E, Gao J, Dogrusoz U, Gross BE, Sumer SO, Aksoy BA, Jacobsen A, Byrne CJ, Heuer ML, Larsson E, Antipin Y, Reva B, Goldberg AP, Sander C, Schultz N: The cBio cancer genomics portal: an open platform for exploring multidimensional cancer genomics data. Cancer Discov 2012, 2:401-404.

35. Galisteo ML, Yang Y, Urena J, Schlessinger J: Activation of the nonreceptor protein tyrosine kinase Ack by multiple extracellular stimuli. Proc Natl Acad Sci U S A 2006, 103:9796-9801.

36. Manser $E$, Leung T, Salihuddin $H$, Tan L, Lim L: A non-receptor tyrosine kinase that inhibits the GTPase activity of p21cdc42. Nature 1993, 363:364-367.

37. van der Horst EH, Degenhardt YY, Strelow A, Slavin A, Chinn L, Orf J, Rong M, Li S, See LH, Nguyen KQ, Hoey T, Wesche H, Powers S: Metastatic properties and genomic amplification of the tyrosine kinase gene ACK1. Proc Natl Acad Sci U S A 2005, 102:15901-15906.

38. Shen F, Lin Q, Gu Y, Childress C, Yang W: Activated Cdc42-associated kinase 1 is a component of EGF receptor signaling complex and regulates EGF receptor degradation. Mol Biol Cell 2007, 18:732-742.

39. Lin Q, Wang J, Childress C, Sudol M, Carey DJ, Yang W: HECT E3 ubiquitin ligase Nedd4-1 ubiquitinates ACK and regulates epidermal growth factor (EGF)-induced degradation of EGF receptor and ACK. Mol Cell Biol 2010, 30:1541-1554. 
40. Modzelewska K, Newman LP, Desai R, Keely PJ: Ack1 mediates Cdc42dependent cell migration and signaling to p130Cas. J Biol Chem 2006 281:37527-37535.

41. Mahajan K, Mahajan NP: Shepherding AKT and androgen receptor by Ack1 tyrosine kinase. J Cell Physiol 2010, 224:327-333.

42. Vogel W: Discoidin domain receptors: structural relations and functional implications. FASEB J 1999, 13(Suppl):S77-S82.

43. Curat CA, Vogel WF: Discoidin domain receptor 1 controls growth and adhesion of mesangial cells. J Am Soc Nephrol 2002, 13(11):2648-2656.

44. Yeh YC, Wu CC, Wang YK, Tang MJ: DDR1 triggers epithelial cell differentiation by promoting cell adhesion through stabilization of E-cadherin. Mol Biol Cell 2011, 22:940-953.

45. Valencia K, Ormazabal C, Zandueta C, Luis-Ravelo D, Anton I, Pajares MJ, Agorreta J, Montuenga LM, Martinez-Canarias S, Leitinger B, Lecanda F: Inhibition of collagen receptor discoidin domain receptor-1 (DDR1) reduces cell survival, homing, and colonization in lung cancer bone metastasis. Clin Cancer Res 2012, 18:969-980.

46. Wang CZ, Hsu YM, Tang MJ: Function of discoidin domain receptor I in HGF-induced branching tubulogenesis of MDCK cells in collagen gel. J Cell Physiol 2005, 203:295-304.

47. Kim HG, Hwang SY, Aaronson SA, Mandinova A, Lee SW: DDR1 receptor tyrosine kinase promotes prosurvival pathway through Notch1 activation. J Biol Chem 2011, 286:17672-17681

48. Hou G, Vogel W, Bendeck MP: The discoidin domain receptor tyrosine kinase DDR1 in arterial wound repair. J Clin Invest 2001, 107:727-735.

49. Hidalgo-Carcedo $C$, Hooper S, Chaudhry SI, Williamson P, Harrington K Leitinger B, Sahai E: Collective cell migration requires suppression of actomyosin at cell-cell contacts mediated by DDR1 and the cell polarity regulators Par3 and Par6. Nat Cell Biol 2011, 13:49-58.

50. Hou G, Vogel WF, Bendeck MP: Tyrosine kinase activity of discoidin domain receptor 1 is necessary for smooth muscle cell migration and matrix metalloproteinase expression. Circ Res 2002, 90:1147-1149.

51. Kamohara H, Yamashiro S, Galligan C, Yoshimura T: Discoidin domain receptor 1 isoform-a (DDR1alpha) promotes migration of leukocytes in three-dimensional collagen lattices. FASEB J 2001, 15:2724-2726.

52. Bhatt RS, Tomoda T, Fang Y, Hatten ME: Discoidin domain receptor 1 functions in axon extension of cerebellar granule neurons. Gene Dev 2000, 14:2216-2228.

53. Vogel WF, Aszodi A, Alves F, Pawson T: Discoidin domain receptor 1 tyrosine kinase has an essential role in mammary gland development. Mol Cell Biol 2001, 21:2906-2917.

54. Lougheed JC, Chen RH, Mak P, Stout TJ: Crystal structures of the phosphorylated and unphosphorylated kinase domains of the Cdc42associated tyrosine kinase ACK1. J Biol Chem 2004, 279:44039-44045.

55. Teo M, Tan L, Lim L, Manser E: The tyrosine kinase ACK1 associates with clathrin-coated vesicles through a binding motif shared by arrestin and other adaptors. J Biol Chem 2001, 276:18392-18398.

56. Chan W, Tian R, Lee YF, Sit ST, Lim L, Manser E: Down-regulation of active ACK1 is mediated by association with the E3 ubiquitin ligase Nedd4-2. J Biol Chem 2009, 284:8185-8194.

57. Prieto-Echague V, Gucwa A, Brown DA, Miller WT: Regulation of Ack1 localization and activity by the amino-terminal SAM domain. BMC Biochem 2010, 11:42.

58. Chan W, Sit ST, Manser E: The Cdc42-associated kinase ACK1 is not autoinhibited but requires Src for activation. Biochem J 2011, 435:355-364

59. Wei X, Walia V, Lin JC, Teer JK, Prickett TD, Gartner J, Davis S, Stemke-Hale K, Davies MA, Gershenwald JE, Robinson W, Robinson S, Rosenberg SA, Samuels Y: Exome sequencing identifies GRIN2A as frequently mutated in melanoma. Nat Genet 2011, 43:442-446.

60. Gao J, Aksoy BA, Dogrusoz U, Dresdner G, Gross B, Sumer SO, Sun Y, Jacobsen A, Sinha R, Larsson E, Cerami E, Sander C, Schultz N: Integrative analysis of complex cancer genomics and clinical profiles using the cBioPortal. Sci Signal 2013, 6:pl1.

doi:10.1186/1471-2407-14-884

Cite this article as: Rudd et al:: Mutational analysis of the tyrosine kinome in serous and clear cell endometrial cancer uncovers rare somatic mutations in TNK2 and DDR1. BMC Cancer 2014 14:884.

\section{Submit your next manuscript to BioMed Central and take full advantage of:}

- Convenient online submission

- Thorough peer review

- No space constraints or color figure charges

- Immediate publication on acceptance

- Inclusion in PubMed, CAS, Scopus and Google Scholar

- Research which is freely available for redistribution 